\title{
The impact of the private provision of WASH services on sustainable economic growth in sub-Saharan Africa
}

\author{
Michael W. Nicholson \\ U.S. Agency for International Development, \\ US Embassy Complex. Nairobi, Kenya
}

\begin{abstract}
This paper analyzes the expanded role of the private sector in the provision of water, sanitation, and hygiene (WASH) services in Africa. Since 2010, private capital has entered the WASH sector throughout the continent via innovative mechanisms such as municipal bonds and equity funds. The surge of capital has attempted to fill the $\$ 2.5$ trillion annual investment gap that the United Nations (2014) estimates for key development sectors. A tension exists, however, between the private-sector-enabled provision of WASH services and key Sustainable Development Goals, particularly offering affordable water and ending chronic poverty. For example, the World Bank (2016) recently found that in countries that declare the right to "free" water, an underserved impoverished class often must pay a much higher price for water than the rich. The current analysis provides an empirical inquiry into the conditions under which the private sector is attracted to the provision of WASH services and estimates its subsequent impact on both economic growth and inclusive development.
\end{abstract}

Key Words: International markets, economic development, water utilities, sanitation JEL Codes: L95, 016, I15, N20, Q25, 055

\begin{abstract}
This paper analyzes the expanded role of the private sector in the provision of water, sanitation, and hygiene (WASH) services in Africa. In the past few years, private capital has surged into the WASH sector throughout Africa through innovative mechanisms such as municipal bonds and equity funds, filling some of the $\$ 2.5$ trillion annual investment gap that the United Nations (2014) estimated for key development sectors. A tension exists, however, between the private-sector-enabled provision of WASH services and the Sustainable Development Goal's focus on ending chronic poverty. For example, the World Bank (2016) recently found that in countries that declare the right to "free" water, an underserved impoverished class must pay a much higher price for water than the rich. The current analysis provides an empirical inquiry into the conditions under which the private sector is attracted to the provision of WASH services and estimates its subsequent impact on both economic growth and inclusive development.
\end{abstract}

\section{INTRODUCTION}

The present research question addresses the impact of the private provision of WASH services on sustainable economic growth in Africa. Specifically, it investigates the impact of private sector investment on water and sanitation services. Water links nearly every Sustainable Development Goal (SDG) as established by the United Nations in 2015. SDG Goal 6 specifically refers to "ensure availability and sustainable management of water and sanitation for all" but also SDG 2 focuses on food security, SDG 3 on clean water and sanitation systems, and SDGs 13, 14 , and 15 on adequate and safe water. Moreover, WASH can be directly linked to poor health, environmental degradation, malnutrition, reduced productivity, and loss of incomes. The lack of access to water has a disproportionate impact on women and girls who spend time fetching 
water that takes away from economic or educational uses and also leaves them at risk of gender-based violence. ${ }^{1}$ Water impacts economic growth and human development, and better water management can yield up to six percent higher GDP. ${ }^{2}$

The political economy of water, moreover, affects inequalities and chronic poverty around the world with dire impacts in sub-Saharan Africa. Water faces both economic scarcity as well as resource scarcity. Climate change and resilience studies document the former, while the emergence of appropriate market signals to allocate water to more productive sectors has increased our understanding of the latter. Carter and Danert (2003) point out that various conceptions of water as a human right, economic good, social good or environmental necessity affect the basis for differentiated arguments concerning private sector participation in the provision of water and sanitation services. Access to water has a substantial cross-cutting relationship with other key development goals including promoting health, financial stability and education; World Bank (2016) argues that "water is the common currency which links nearly every SDG and it will be a critical determinant of success."

Water's impact can be felt across a range of basic human conditions. Wolf (2009) finds that increased access to clean water and sewerage can reduce the likelihood of contracting illness, thus enhancing productivity and alleviating poverty. It also benefits business productivity, protecting the business cycle against down time. Low access to water and sewerage in schools often drives young girls to drop out, which erodes the potential youth labor force and thus harms the local economy. Limited capital investment in water and sewerage in sub-Saharan Africa has created a climate in which existing systems are subject to lack of maintenance and high physical and financial leakages.

Water's role as both a public and private good creates counter-intuitive results-when water is perceived as a right to access, generally, services tend to be more expensive for the poor. In Kenya, for example, the 2010 Constitution declares under Article 43 (1) (d) that "Every person has the right-to clean and safe water in adequate quantities"; ${ }^{3}$ however, Wolf (2009)'s analysis suggests Kenyan water is eight times more expensive for the poor in the capital city of Nairobi.

Gunatilake and Carangal (2008) investigate implications of the privatization trend in the provision of water and sanitation services. They point out that 68 countries introduced private sector provisions, between 1990 and 2007. This context raises very important questions about the role of the private sector in providing WASH services. Is it efficient? Is it sustainable? Does it lead to inclusive development? The current analysis frames these questions by identifying the conditions under which private sector investment increases the provision of water and sanitation services in sub-Saharan Africa.

\section{BACKGROUND: ADDRESSING THE FINANCING GAP BY LEVERAGING THE PRIVATE SECTOR}

Private provision of water and sanitation services often follows signals of economic returns. Hutton, Haller \& Bartam (2007), for instance, finds that every \$US 1 invested in water supply and sanitation services leads to $\$ 5$ to $\$ 46$ dollars in returns, an effect most pronounced in the

\footnotetext{
1 The 1 June 2016 Washington Post article, "African women are breaking their backs to get water for their families," describes the specific physical impact on women and children that include 'musculoskeletal damage and early degenerative bone and soft tissue damage.'

2 World Bank (2016)

3 https://www.kenyaembassy.com/pdfs/the\%20constitution\%20of\%20kenya.pdf
} 
least-developed countries. Time savings yield the greatest return to investment in water, as the close proximity to the user provides people (mainly women and girls) more time for productive activities with social economic contributions as they must invest less of it in hauling water--individuals in households with improved water access can save an average of 30 to 90 minutes a day for other tasks such as working. Nauges \& Strand (2014) show in Ghana a decrease in the burden of water hauling activity correlates with a significant increase in female student attendance; poor countries with access to improved water facilities experienced an average annual growth of 3.7 percent, whereas countries with the same per capita income but without such access have an annual growth of only 0.1 percent.

The Stockholm International Water Institute (2005) finds that efficient access to water and sanitation services improves productivity while also reducing poverty, as health systems strengthen improved overall well-being. They note that fiscal and monetary policy affect both demand and investment in water-related activities, as economic sectors such as agriculture are contingent on water and sanitation services. The report remarks that a 0.3 percent increase in investment in household access to safe water correlates to a 1.0 percent increase in GDP.

A 2012 report published by the World Health Organization (WHO) estimated that poor sanitation and hygiene in many countries translates into a global economic loss of roughly $\$ 260$ billion annually. In assessing the total societal costs of poor WASH services, the United Nations (2015) estimated that close to 64.2 million disability-adjusted life years are attributed to unsafe water, poor sanitation and hygiene practices, including 52.5 million in low-income countries. The lack of access to safe water is pervasive in Africa, where 50 percent of the population lacks access to improved sanitation and relatively higher proportions of people practicing open defecation. While urban regions have better coverage, rural regions in developing countries are five times more likely to be without access to clean water and more than twice as likely to suffer from inadequate sanitation. Less than half the rural population in developing countries has access to improved sanitation and over one-fifth lack access to improved sanitation.

Clarke, Kosec and Wallsten (2004) find an empirical link between the private provision of water and sanitation services and increased production rates. They describe political and legal difficulties that obstruct private sector operators from engaging the water sector and suggest that monopolies granted over water distribution to private sector players instigate a great deal of backlash from citizens. They further suggest that the costs of supplying water mainly consist of distribution costs, due to the impracticality of transporting water over long distances.

Odaro (2012) suggests that past approaches to privatization have stirred resentment but identifies successful cases of public-private partnerships in Senegal and Cote d'Ivoire, due to a key role for the local governments and a longer duration of contracting. The poor pay higher prices for water because they tend not to have connections to public services and therefore must rely on expensive private alternatives.

Market challenges due to informal distribution systems and informal settlements have an impact on WASH service provision. The African Development Bank finds that nearly 50 per cent of water supply in sub-Saharan Africa is unaccounted for, exacerbating low revenue and financial strain of water service providers-both the ability and the willingness to pay impact user payments and connection fees. The UNDP estimates that only 0.5 percent of GDP is dedicated toward public spending for water and sanitation in low-income countries. The subSaharan Africa figures for sanitation investment are even lower, averaging only about 12-15 percent of total water and sanitation expenditure. 
Financing also plays a major role. Gurria (2006) finds that the maintenance and long-term health of private provision of WASH projects depends on financial repayment by either consumers or the public budget. GIZ (2010) suggests that pro-poor rural financial services should enable the poor and low-income population to access water and sanitation facilities by offering loans, savings, and payment services, as well as insurance all designed to meet the demands of people with low income in rural areas, relating to both agricultural and nonagricultural activities.

Africa has not met public infrastructure needs. As Thoenen (2007) argues, historically, stateowned enterprises managing these services have failed to meet the growing demand of urban and rural regions. Unlike in Asia and North America, where an adequately-sized urban area can access capital markets to finance large infrastructure projects, these options are not regularly available in sub-Saharan Africa. A lack of adequate secondary markets compounds the poor state of infrastructure. Most sub-Saharan African countries' credit ratings are insufficient to access global capital markets. Thoenen finds that the public provision of public goods in water and sanitation, much like the provision of health, leads to sub-optimal demand when the private sector takes the lead without government intervention. He provides an example of successful private sector provision of water sources in Mauritania that employed a decentralized, community-centered approach to water provision focusing on small-scale independent water providers for small towns. In this scenario, local governments were empowered to delegate water provision to private operators.

Only 5.5 percent of the total volume of private infrastructure investment is dedicated to the WASH sector in sub-Saharan Africa, compared to 33.7 percent of total PPI volume globally. ${ }^{4}$ Of these investments, 9.9 percent of projects in the water and sewage sector were either distressed or outright failed-tourism and telecommunication tend to experience a higher success rate of private participation due to clearly defined boundaries between risk definition and expected return.

Budds and McGranahan (2003) found that private finance generated very little investment in the sewer and water sector, with most of the financing coming from the public sector or multilateral loans that identify low-income groups as unattractive customers due to their high degree of risk. As a result, relevant contracts excluded those regions that were most in need of the sewer and water infrastructure services, while the private sector remains driven by profit and returns. In most cases, multilateral financial organizations seek large-scale projects exceeding \$100 million and upwards of one million of inhabitants in contrast with the usual water project size ranging between \$10-50 million, which also requires mitigation of political and financial risk. Parker, Kirkpatrick and Theodorakopoulou (2005) identify a "reality gap" between privatization and poverty reduction through case studies of privatization efforts in Argentina, Bolivia, Mexico and Nicaragua, which suggest adverse distributional effects on the lower end of the income ladder primarily due to job losses.

In some cases, the private provision of WASH services has caused a spike in prices for households. In a cross-country panel regression, Wolf (2009) found that for the poorest quintile of urban households in Uganda, water payments accounted for 22 percent of the average income. In Nairobi and Accra, prices paid in low-income settlements with little access to the public provision are around eight times higher than those paid by high-income residents. These tendencies are further compounded by the higher rates of urban migration and

${ }^{4}$ https://ppi.worldbank.org/ 
expansion of slums. Wolf further identified limited effects of Official Development Assistance (ODA) for water and sanitation on access, finding a positive and significant coefficient only for urban sanitation. She does not report results for private participation, as it reduces the number of observations substantially and yields no statistical significance for the coefficients. She concludes that better data, such as different types of finance for water and sanitation, would help identify potential impact on outcomes such as access to WASH services in urban and rural areas.

\section{PROBLEM STATEMENT}

A tension exists between the private-sector-enabled provision of WASH services and the Sustainable Development Goal's focus on ending chronic poverty. The SDGs promote equitable access to clean and affordable water sources in order to improve socio-economic outcomes through lower health risks and reduced time spent on water hauling activities generating higher productivity in areas such as education and income generation; however, the private provision of WASH services often conflicts with these goals instead of supporting them. For the poor, free water is often anything but free, due to their relatively higher cost of access.

This paper analyzes the conditions under which private sector is attracted to the provision of WASH services. Research by large agencies continually point out that global rural populations have much lower rates of using improved water sanitation compared to urban dwellers. Moreover, these disparities can be as pronounced between disaggregated urban areas. As UNICEF (2015) points out, only 51 percent of the global rural population uses improved sanitation as compared to 82 percent for urban dwellers. The disparities can be just as pronounced between urban areas-only 10 percent of the population has access to piped water in the Kenyan port city of Mombasa, compared to 45 percent for Kenya's urban population as a whole.

\section{RESEARCH OBJECTIVES}

The immediate analysis compares development "aid" in the form of Overseas Development Assistance (ODA) to private sector participation in water and sanitation provisions. This research objective requires ambitious data collection that includes the cost of WASH services as well as various forms of financing. It anticipates the following structural equation:

$$
\text { WASH }=\mathrm{f}(\mathrm{g}(\mathrm{x}, \mathrm{y}))
$$

where $\mathrm{x}$ indicates private provision and $\mathrm{y}$ indicates public provision, and the dependent variable WASH identifies relevant SDG indicators, such as access to improved water sanitation service, the degree of integrated water services management, or the percentage change in water use efficiency over time.

The next section details the research design and methodology based on proximate data limitations.

\section{RESEARCH DESIGN/METHODOLOGY}

For the preliminary analysis, we collected annual indicators for 43 sub-Saharan countries from 2002 to 2014, providing 519 unique data points. We use these years as the unit of analysis due to data availability. Table 1 defines the variables and provides their source. 
Table 1: Data definition and source

\begin{tabular}{|c|c|c|}
\hline Variable & Definition & Source \\
\hline ODA_Wat_Lg & Water supply - large systems & QWIDS -- https://stats.oecd.org/qwids/ \\
\hline ODA_San_Lg & Sanitation - large systems & QWIDS -- https://stats.oecd.org/qwids/ \\
\hline ODA_WatSan_Lg & $\begin{array}{l}\text { Water supply and sanitation - } \\
\text { large systems }\end{array}$ & QWIDS -- https://stats.oecd.org/qwids/ \\
\hline ODA_WatSan_Total & $\begin{array}{l}\text { I.4. Water Supply \& Sanitation, } \\
\text { Total }\end{array}$ & QWIDS -- https://stats.oecd.org/qwids/ \\
\hline WATER & $\begin{array}{l}\text { Improved water source (\% of } \\
\text { population with access) }\end{array}$ & $\begin{array}{l}\text { WHO/UNICEF Joint Monitoring Programme } \\
\text { (JMP) for Water Supply and Sanitation } \\
\text { (http://www.wssinfo.org/). }\end{array}$ \\
\hline WATURB & $\begin{array}{l}\text { Improved water source, urban } \\
\text { (\% of urban population with } \\
\text { access) }\end{array}$ & $\begin{array}{l}\text { WHO/UNICEF Joint Monitoring Programme } \\
\text { (JMP) for Water Supply and Sanitation } \\
\text { (http://www.wssinfo.org/). }\end{array}$ \\
\hline WATRUR & $\begin{array}{l}\text { Improved water source, rural } \\
\text { ( } \% \text { of rural population with } \\
\text { access) }\end{array}$ & $\begin{array}{l}\text { WHO/UNICEF Joint Monitoring Programme } \\
\text { (JMP) for Water Supply and Sanitation } \\
\text { (http://www.wssinfo.org/). }\end{array}$ \\
\hline SANTOT & $\begin{array}{l}\text { Improved sanitation facilities } \\
\text { (\% of population with access) }\end{array}$ & $\begin{array}{l}\text { WHO/UNICEF Joint Monitoring Programme } \\
\text { (JMP) for Water Supply and Sanitation } \\
\text { (http://www.wssinfo.org/). }\end{array}$ \\
\hline SANURB & $\begin{array}{l}\text { Improved sanitation facilities, } \\
\text { urban ( } \% \text { of urban population } \\
\text { with access) }\end{array}$ & $\begin{array}{l}\text { WHO/UNICEF Joint Monitoring Programme } \\
\text { (JMP) for Water Supply and Sanitation } \\
\text { (http://www.wssinfo.org/). }\end{array}$ \\
\hline SANRUR & $\begin{array}{l}\text { Improved sanitation facilities, } \\
\text { rural ( } \% \text { of rural population } \\
\text { with access) }\end{array}$ & $\begin{array}{l}\text { WHO/UNICEF Joint Monitoring Programme } \\
\text { (JMP) for Water Supply and Sanitation } \\
\text { (http://www.wssinfo.org/). }\end{array}$ \\
\hline Private Sector & $\begin{array}{l}\text { Investment in water and } \\
\text { sanitation with private } \\
\text { participation (current US\$) }\end{array}$ & $\begin{array}{l}\text { World Bank, Private Participation in } \\
\text { Infrastructure Project Database } \\
\text { (http://ppi.worldbank.org). }\end{array}$ \\
\hline
\end{tabular}

The above selection allows for a longitudinal cross-country panel regression of ODA and private investment on water and sanitation services into the percentage of population with improved access. Following Wolf (2009), the relevant outcomes for access are disaggregated to 'Urban' and 'Rural' to provide information about the inclusiveness of relevant development outcomes.

The optimal ODA variable "Total Water Supply \& Sanitation" is not available at a disaggregated level to Urban and Rural, and thus we incorporate the correlated "Water supply and sanitation - large systems" into the analysis. Similarly, as the listed variable "Investment in water and sanitation with private participation" is not available for countries in sub-Saharan Africa, we incorporate the correlated "Investment in telecoms with private participation" as a proxy.

5 Wolf (2009) finds that the share of telephone subscribers is associated with better outcomes for water and rural sanitation, suggesting better coordination of different public sector development. 


\section{FINDINGS AND INTERPRETATION}

Table 2 displays results for longitudinal cross-country panel regressions of water and sanitation access against two primary sources of financing: Official Development Assistance (ODA) and private sector investment. Fixed effects are included by country and by year with tstatistics shown in parentheses.

Table 2: ODA and Private Sector impacts on WASH service provision ${ }^{6}$

\begin{tabular}{|c|c|c|c|c|c|c|c|c|}
\hline \multicolumn{9}{|c|}{ Access to Water* } \\
\hline & \multicolumn{2}{|c|}{ WATER } & \multicolumn{3}{|c|}{ WATURB } & \multicolumn{3}{|c|}{ WATRUR } \\
\hline Private Sector & $\begin{array}{c}0.002 \\
(2.290)\end{array}$ & $\begin{array}{c}0.002 \\
(2.780)\end{array}$ & $\begin{array}{c}0.001 \\
(1.040)\end{array}$ & $\begin{array}{c}0.001 \\
(1.280)\end{array}$ & $\begin{array}{l}-0.001 \\
(-1.29)\end{array}$ & $\begin{array}{c}0.002 \\
(2.040)\end{array}$ & $\begin{array}{c}0.002 \\
(2.570)\end{array}$ & $\begin{array}{l}-0.004 \\
(-4.49)\end{array}$ \\
\hline ODA_WatSanTotal & $\begin{array}{c}0.082 \\
(7.703)\end{array}$ & & $\begin{array}{c}0.016 \\
(1.910)\end{array}$ & & & $\begin{array}{c}0.088 \\
(7.580)\end{array}$ & & \\
\hline ODA_WatSanLg & & $\begin{array}{c}0.070 \\
(2.930)\end{array}$ & & $\begin{array}{l}-0.005 \\
(-0.26)\end{array}$ & & & $\begin{array}{c}0.081 \\
(3.130)\end{array}$ & \\
\hline ODA_Wat_Lg & & & & & $\begin{array}{c}0.007 \\
(0.540)\end{array}$ & & & $\begin{array}{r}0.029 \\
(1.430)\end{array}$ \\
\hline $\mathrm{n}$ & 519 & 440 & 519 & 440 & 160 & 519 & 440 & 160 \\
\hline countries & 43 & 43 & 43 & 43 & 40 & 43 & 43 & 40 \\
\hline $\mathrm{F}$ & 34.55 & 8.88 & 2.6 & 0.84 & 1.11 & 32.81 & 8.88 & 12.33 \\
\hline R-sq. & 0.1272 & 0.043 & 0.0108 & 0.0042 & 0.0184 & 0.1216 & 0.043 & 0.1729 \\
\hline \multicolumn{9}{|c|}{ Access to Sanitation* } \\
\hline & \multicolumn{2}{|c|}{ SANTOT } & \multicolumn{3}{|c|}{ SANURB } & \multicolumn{3}{|c|}{ SANRUR } \\
\hline Private Sector & $\begin{array}{c}0.000 \\
(0.460)\end{array}$ & $\begin{array}{c}0.000 \\
(0.850)\end{array}$ & $\begin{array}{c}0.000 \\
(0.870)\end{array}$ & $\begin{array}{c}0.001 \\
(1.220)\end{array}$ & $\begin{array}{l}-0.002 \\
(-3.62)\end{array}$ & $\begin{array}{c}0.000 \\
(-0.43)\end{array}$ & $\begin{array}{c}0.000 \\
(-0.05)\end{array}$ & $\begin{array}{l}-0.001 \\
(-1.21)\end{array}$ \\
\hline ODA_WatSanTotal & $\begin{array}{l}0.037 \\
(5.64)\end{array}$ & & $\begin{array}{c}0.030 \\
(4.960)\end{array}$ & & & $\begin{array}{c}0.029 \\
(4.710)\end{array}$ & & \\
\hline ODA_WatSanLg & & $\begin{array}{c}0.030 \\
(1.950)\end{array}$ & & $\begin{array}{c}0.031 \\
(2.280)\end{array}$ & & & $\begin{array}{c}0.021 \\
(1.450)\end{array}$ & \\
\hline ODA_San_Lg & & & & & $\begin{array}{c}0.007 \\
(0.550)\end{array}$ & & & $\begin{array}{r}0.009 \\
(0.380)\end{array}$ \\
\hline $\mathrm{n}$ & 519 & 440 & 519 & 440 & 80 & 519 & 440 & 80 \\
\hline countries & 43 & 43 & 43 & 43 & 27 & 43 & 43 & 27 \\
\hline $\mathrm{F}$ & 16.46 & 2.42 & 13.31 & 3.59 & 7.33 & 11.07 & 1.05 & 0.93 \\
\hline $\begin{array}{l}\text { R-sq. } \\
\text { *FE by country and year }\end{array}$ & 0.0649 & 0.0121 & 0.0532 & 0.0179 & 0.2233 & 0.0446 & 0.0053 & 0.0353 \\
\hline
\end{tabular}

Private sector investment and development assistance have a positive, statistically-significant impact on Total Water access, but only ODA is significant for Total Sanitation access. The immediate interpretation is that private provision of sanitation services has not yet yielded a direct impact on overall water access for the general population, which anticipates future research that takes into account community-led total sanitation initiatives.

Neither ODA nor private sector investment has a statistically significant impact on Urban Water access. However, the data suggest very strong interactions between development assistance and private sector involvement in Rural Water access. Aggregated ODA, whether 
total or large projects, shows a positive impact on access to water and a related positive, statistically significant impact of private investment. However, for ODA limited to large water projects, private provision has a negative impact. These results may be pulling out some of the challenges and controversies associated with the private provision of WASH services in rural areas.

With one key exception, all the regressions for sanitation access indicate a positive statistically significant impact of development assistance and no statistical relationship for the private sector. An effect similar to Rural Water arises in the Urban Sanitation regression, in which the presence of development assistance disaggregated to large projects suggests a negative, statistically significant impact of private investment on access. While this result could be related to limited data availability, it might also reflect complexities that arise in the interaction of development assistance and private investment.

\section{CONCLUSION}

This paper provides a preliminary investigation into the tension between the private-sectorenabled provision of WASH services and the Sustainable Development Goal's focus on ending chronic poverty, such as when the poor must pay more for water otherwise regarded as "free." The current analysis analyzes the relative impact of development assistance funds and privatesector supported activities for water and sanitation access in sub-Saharan Africa, including both urban and rural areas.

The next step will be to identify and collect data that can make relevant comparisons between the private and public provision of water and sanitation projects. The WHO/UNICEF Joint Monitoring Programme for Water Supply and Sanitation ${ }^{7}$ data proves useful in the present analysis as a baseline for comparing development and private sector engagement in urban and rural areas. However, the extensive use of proxy variables allows the results to be interpreted as merely a guide to broader trends instead of ascertaining specific policy prescriptions.

The ideal data set includes disaggregated investments over time, including the types of financing, as private and public investments arrive in many different flavors. In addition, the extended project will benefit from data that includes characteristics outlining the context of investment. Examples include control of corruption, decentralization, urbanization and population density, adult literacy rates, the role of Community-Led Sanitation, and types of financing.

Ultimately, any sustainable investment must be entirely void of development assistance. The popularity of the current trends towards leveraging private investment stems in large part from the expectation that profit-oriented investments create their own incentives for longterm development. However, the social value of these investments is limited to the extent that access to affordable and clean water and sanitation can be achieved by vulnerable populations, including those in extreme poverty.

\section{WORKS CITED}

Budds, J., and G. McGranahan. 2003. "Privatization and the Provision of Urban Water and Sanitation in Africa, Asia, and Latin America." IIED Human Settlements Discussion Paper Series (Water 1). London.

Carter, Richard C. and Kerstin Danert. 2003. "The private sector and water and sanitation services - policy and poverty issues." Journal of International Development 15: 1067-1072.

7 http://www.wssinfo.org/ 
Clarke, G., K. Kosec, and S. Wallsten. 2004. "Has Private Participation in Water and Sewerage Improved Coverage? Empirical Evidence from Latin America.” World Bank Policy Research Working Paper Series 3445. Washington, DC.

Hutton, G., Haller, L. and Bartram, J., 2007. Global cost-benefit analysis of water supply and sanitation interventions. Journal of water and health, 5(4), pp.481-502.

GIZ (2010) "Pro-Poor Financial Services for Rural Water Linking the Water Sector to Rural Finance." http://ccsl.iccip.net/gtz2010-0142en-financial-services-rural-water.pdf

Gunatilake, Herath and Mary Jane F. Carangal. May 2008. "Privatization Revisited: Lessons from Private Sector Participation in Water Supply and Sanitation in Developing Countries” Asian Development Bank.

Gurria, Angel. 2006. "Task Force on Financing Water for All Report 1: Enhancing Access to Finance for Local Governments Financing Water for Agriculture" World Water Council.

Nauges, C. and Strand, J., 2014. Water hauling and girls' school attendance: Some new evidence from Ghana. Environmental and Resource Economics, pp.1-24.

Noll, Roger G. 2002. "The Economics of Urban Water Systems." In Thirsting for Efficiency: The Economics and Politics of Urban Water System Reform, edited by Mary M. Shirley, 43- 64. Oxford UK: Pergamon.

Odaro, Esohe Denise. 2012. "Causes of Poor Service Delivery in Africa and Their Impact on Development" Consilience: The Journal of Sustainable Development 7(1): 34-45.

Parker, David, Colin Kirkpatrick and Catarina Figueira-Theodorakopoulou. June 2005. "Infrastructure Regulation and Poverty Reduction in Developing Countries: A Review of the Evidence and Research Agenda." Centre on Regulation and Competition, Institute for Development Policy and Management, University of Manchester.

Stockholm International Water Institute. 2005. "Making water a part of economic development: the economic benefits of improved water management and services. " Stockholm: Stockholm International Water Institute.

Thoenen, R., 2007. Private Sector Participation in the Provision of Basic Infrastructure, ATPC Work in Progress No. 66, UNECA, Addis Ababa.

UNICEF. 2015 "Water, sanitation and hygiene: The case for support."

https://www.unicef.org/publicpartnerships/files/WASHTheCaseForSupport.pdf

Wolf, Susana. 2009. “Determinants of Unequal Access to Water and Sanitation.” New York: UN-OHRLLS.

World Bank. 2016. "High and Dry: Climate Change, Water, and the Economy."

http://www.worldbank.org/en/topic/water/publication/high-and-dry-climate-change-water-and-the-economy

World Health Organization. 2012. "Global costs and benefits of drinking-water supply and sanitation interventions to reach the MDG target and universal coverage." 